\title{
Impacts of logging roads on tropical forests
}

\author{
Kleinschroth, Fritz; Healey, John
}

\section{Biotropica}

DOI:

10.1111/btp.12462

Published: 01/09/2017

Peer reviewed version

Cyswllt i'r cyhoeddiad / Link to publication

Dyfyniad o'r fersiwn a gyhoeddwyd / Citation for published version (APA):

Kleinschroth, F., \& Healey, J. (2017). Impacts of logging roads on tropical forests. Biotropica, 49(5), 620-635. https://doi.org/10.1111/btp.12462

\footnotetext{
Hawliau Cyffredinol / General rights

Copyright and moral rights for the publications made accessible in the public portal are retained by the authors and/or other copyright owners and it is a condition of accessing publications that users recognise and abide by the legal requirements associated with these rights.

- Users may download and print one copy of any publication from the public portal for the purpose of private study or research.

- You may not further distribute the material or use it for any profit-making activity or commercial gain

- You may freely distribute the URL identifying the publication in the public portal ?
}

Take down policy

If you believe that this document breaches copyright please contact us providing details, and we will remove access to the work immediately and investigate your claim. 


\title{
Impacts of logging roads on tropical forests
}

\author{
Authors: \\ Fritz Kleinschroth $^{1,2^{*}}$ and John R. Healey ${ }^{3}$ \\ ${ }^{1}$ Institute of Terrestrial Ecosystems, Department of Environmental Systems Science, ETH \\ Zurich, Universitätstrasse 16, 8092 Zürich, Switzerland \\ ${ }^{2}$ Forêts et Sociétés, Département Environnements et Sociétés, CIRAD, Campus International \\ de Baillarguet TA C-105/D, 34398 Montpellier Cedex 5, France \\ ${ }^{3}$ School of Environment, Natural Resources and Geography, Bangor University, Bangor, \\ Gwynedd, LL57 2UW, UK \\ * corresponding author, email: fritz.kln@gmail.com
}




\section{ABSTRACT}

2 Road networks are expanding in tropical countries, increasing human access to remote forests

3 that act as refuges for biodiversity and provide globally important ecosystem services.

4 Logging is one of the main drivers of road construction in tropical forests. We evaluated

5 forest fragmentation and impacts of logging roads on forest resilience and wildlife,

6 considering the full life cycle of logging roads. Through an extensive evidence review we

7 found that for logging road construction, corridors between 3 and $66 \mathrm{~m}$ (median $20 \mathrm{~m}$ ) width

8 are cleared, leading to a loss of 0.6 to 8.0 percent (median 1.8\%) of forest cover. More severe

9 impacts are increased fire incidence, soil erosion, landslides and sediment accumulation in

10 streams. Once opened, logging roads potentially allow continued access to the forest interior,

11 which can lead to biological invasions, increased hunting pressure and proliferation of

12 swidden agriculture. Some roads, initially built for logging, become converted to permanent,

13 public roads with subsequent in-migration and conversion of forest to agriculture. Most

14 logging roads, however, are abandoned to vegetation recovery. Given the far-reaching

15 impacts of the roads that become conduits for human access, its control after the end of

16 logging operations is crucial. Strategic landscape planning should design road networks that

17 concentrate efficient forest exploitation and conserve roadless areas.

\section{KEY WORDS}

20 Road ecology, forest management, reduced impact logging, invasions, forest resilience,

21 forest degradation, deforestation, pantropical 
ROADS HAVE A PROMINENT ROLE IN PUBLIC PERCEPTION OF TROPICAL FOREST DESTRUCTION.

23 Images of the fishbone-like patterns of deforestation along the Transamazonian Highway in

24 Brazil have become one of the symbols of global deforestation threats. This may be

25 comparable with the pictures of monotonous oil palm plantations and cattle pastures divided

26 by a sharp line from the heterogeneous canopy of old-growth forests. Such images are a

27 powerful visual representation of human dominance and destruction of tropical forests.

28 However, as with all iconic images, they create the danger that a single case is used as the

29 basis for generalizations about complex interactions occurring in tropical forest landscapes

30 around the world - narrowing the imagination of both the public and the scientific

31 community.

32 The global threats of road development are often underlined by the projection that by 2050 ,

33 more than 25 million more paved road lane-km will be built worldwide, with $90 \%$ being

34 located in non-OECD countries (Dulac 2013). It is not appropriate to apply this prediction

35 directly to tropical forests, where predominantly unpaved roads are built, but roads are now a

36 prevailing feature of tropical forests globally, often due to widespread selective logging

37 activities. Remote sensing analyses have documented the expansion of logging road networks

38 throughout the tropics (e.g. Laporte et al. 2007, Gaveau et al. 2014, Ahmed, Souza, et al.

39 2013, Kleinschroth, Healey, Gourlet-Fleury, et al. 2016, Arima et al. 2008). Annual growth

40 rates are reported of up to $40 \mathrm{~km}$ of new roads per $10000 \mathrm{~km}^{2}$ of forest area (Brandão \&

41 Souza 2006), sometimes unconstrained by the boundaries of officially protected areas

42 (Curran et al. 2004). Logging road networks, however, are highly dynamic in space and time

43 and their impacts might differ from other types of road in tropical forests (Kleinschroth et al.

44 2015). Surprisingly, a comprehensive review of impacts for the full "life-cycle" of logging

45 roads is largely missing. 
46 Fifty-three percent or 400 million hectares of the natural tropical permanent forest

47 estate comprises (timber) production forest (Blaser et al. 2011). In the face of such

48 widespread logging activities in tropical forests worldwide, consensus is growing about the

49 importance of the state of logged forests for their conservation value and the need to reduce

50 logging impacts to maintain major ecosystem services while allowing timber extraction for

51 economic reasons (Putz et al. 2012, Edwards et al. 2011). Logging roads have a particular

52 role in reducing impacts of tropical logging as they are the most costly, damaging and visible

53 part of selective logging activities. At low harvest levels $(<4$ trees per ha), which are

54 common in many tropical regions, damage from road construction is much higher than from

55 tree felling (Gullison \& Hardner 1993, Sist et al. 2003).

Identifying tropical forest degradation is difficult, especially on a larger scale. Roads,

57 as the most visible indicator of human activity in tropical forests, are therefore often used as

58 the main indicator to estimate the global extent of forest degradation (see e.g. Lewis et al.

59 2015). The underlying logic is that forest areas that are not accessible by roads are considered

60 to be the least degraded because they provide habitat that is not immediately affected by

61 human activities on an industrial scale (Potapov et al. 2008). The possibility that responsible

62 forest management can avoid degradation is not taken into account in these approaches (Putz

63 et al. 2012). "The first cut is the deepest" (Laurance et al. 2015) and logging roads are often

64 the first to penetrate old-growth forests, opening what has been termed "a Pandora's box" of

65 environmental problems (Laurance et al. 2009). Road building strategies therefore advocate

66 to concentrate road building (Laurance et al. 2014) and to set-aside high conservation-value

67 forest areas from logging to keep them entirely road-free (Clements et al. 2014). More

68 specific evidence, however, is needed about which impacts are directly associated with roads

69 built for logging activities. Many publications do not make a distinction between roads built

70 and used for logging and those for other purposes such as public transportation (e.g. Barber et 
71 al. 2014, Ahmed, Ewers et al. 2013, Pfaff et al. 2007). The majority of logging roads differ

72 greatly from other linear forest clearings for infrastructure, in that they are used only for a

73 certain purpose and for a limited amount of time.

Where logging takes place in industrial concessions, logging companies are often the

75 only official users of logging road networks, which are built and maintained according to just

76 the companies' immediate economic interests (solely to provide access to the forest for heavy

77 machinery and to allow trucks to transport harvested trees to timber processing sites).

78 Typically, such roads are unpaved but the investment in their engineering is based on a

79 network hierarchy with at least two different levels: (i) a few primary roads built to

80 permanently access the forest concession as a whole; (ii) many secondary "dead-end" roads,

81 branching off the primary roads and only built for use in a short period of timber harvesting

82 from a limited forest area (months to a few years) before being abandoned. Skid trails, used

83 to extract logs by dragging them with heavy machinery from their felling site to "logging

84 yards" (or "landing sites") on the roadside, where they are lifted onto trucks, are typically

85 much shorter and narrower than the forest roads constructed for use by trucks, and are often

86 under the canopy of adjacent trees. They constitute a different category of environmental

87 impact on the forest and are not included in this review.

88 Habitat fragmentation is one of the main impacts of roads in tropical forests.

89 However, there is a lack of evidence review about aspects of fragmentation related to road

90 width, forest cover cleared for road construction, and about how animal movements are

91 affected. To meet this need for evidence, it is crucial to assess logging roads not simply as a

92 static component in the landscape but instead to consider their whole "life cycle". This

93 includes the intense activity during the construction phase, the main primary use phase (often

94 timber extraction), followed by alternative fates such as road abandonment followed by

95 gradual recovery of forest cover versus maintenance of the road as a more permanent 
96 landscape feature due to continuing use, sometimes associated with upgrade to a public road.

97 Given the dynamic nature of tropical forests and the complexity of current degradation and

98 conversion processes, information is scarce about the relative importance and persistence of

99 each phase in the road life-cycle. We evaluated the short- and long-term impacts of logging

100 roads on tropical forest vegetation, fauna, soil and hydrology by addressing the following

101 questions: (1) To what extent are logging roads fragmenting forests by dissecting formerly

102 connected forests into smaller units? (2) How do roads affect forest resilience and wildlife

103 populations? (3) How long-lasting are each of these impacts in dynamic tropical forest

104 environments? (4) How commonly do roads built for logging undergo a transition to public

105 roads that can eventually lead to large-scale deforestation? (5) How can such impacts be

106 reduced through preventative or post hoc interventions?

108 METHODS

109 Given the relatively wide scope of this evidence review, we considered all literature dealing

110 with the impacts of roads initially built for logging in tropical forests around the world. We

111 conducted a comprehensive database search in Web of Science and CAB-direct, using the

112 keywords: "logging” AND "road*” AND “impact" AND "tropic*”. This generated 156

113 results for Web of Science and 393 for CAB Direct. In an iterative process, we broadly

114 selected relevant publications based on title and abstract. These selected papers led to further

115 sources through backward tracking (based on their reference lists) and forward tracking

116 (based on subsequent papers in which they have been cited). Other reviews on related

117 subjects (Kleinschroth, Gourlet-Fleury, et al. 2016, Laurance et al. 2009, Hawthorne et al.

118 2011, Picard et al. 2012) proved to be particularly useful in identifying additional

119 publications. All these references were added to our existing literature database (see data 
availability statement below), covering more than 1300 publications related to road ecology and tropical forest management. This database allowed comprehensive full text searching - in addition to that enabled by online search engines. We searched all documents for the keywords "logging" and "road". All selected documents then underwent a critical appraisal of the methods and results used in each study. Inclusion criteria were that they must present original evidence of impacts based on empirical methods or first-hand observations. The relevant information was extracted and grouped into thematic categories. In parallel, we extracted quantitative results for all road width measurements of logging roads and the proportion of forest area that had been cleared for road building (i.e. disturbed area as a percentage of overall logged area).

The search strategy resulted in 178 publications that were used to provide the evidence for further review. Overall, the analysed studies showed strong contrasts in the methods used, with a dominance of anecdotical observations made on individual roads. Given these empirical limitations and strong differences in focus, we did not apply any weighing between the studies. The quantitative results are therefore only indicative. Many sources do not document how exactly they measured road corridor width, but the most straightforward way on the ground is to measure the distance between the stems of the two closest trees on either side of the road track (Figure 1). We did not include measurements entirely based on remote sensing, as optical sensors (in contrast to LIDAR) only allow the estimation of canopy opening from above. Evidence reviews based on published literature carry a risk of publication bias (Huntingdon 2011), due to failure of researchers to publish non-significant or non-anticipated results. We have no evidence for such publication bias but noted that most of the published studies reported negative effects of roads on the forest. 


\section{RESULTS AND DISCUSSION}

145 FRAGMENTATION IMPACTS. - The first and most obvious road impact is linear clearing of

146 forest cover. Road tracks (Figure 1) used by logging vehicles had a median reported width of

$1476.4 \mathrm{~m}$ (primary roads) and $5.1 \mathrm{~m}$ (secondary roads). The range of track widths is relatively

148 small (3 $\mathrm{m}$ to $7.9 \mathrm{~m}$, Table 1) but most logging road construction involves the felling of trees

149 in much wider corridors than just the road track itself. This is due to traffic safety reasons and

150 in order to let the sun dry the road surface after rain (Sessions 2007). Overall medians for full

151 corridor width are $24.85 \mathrm{~m}$ for primary and $15.1 \mathrm{~m}$ for secondary roads but there are strong

152 regional contrasts. Few measurements are available for Asia, but secondary logging roads in

153 tropical America (range 3 - $10.5 \mathrm{~m}$ ) have generally narrower corridors than in Africa (15.1 -

$154 \quad 66.6 \mathrm{~m}$, Table 1).

155 The proportion of forest that is cleared for road construction depends on both road

156 length density and road width. The most commonly used reference area for this proportion is

157 the total logged area, for example that delimited by annual logging blocks. The global median

158 percentage is 1.7 percent of the forest area, with the range of values being $0.6-8$ percent in

159 America, 0.74-6.4 percent in Africa and 3.3-4.8 percent in Asia (Table 2). The full clearing

160 of forest for road construction leads to carbon emissions from destroyed biomass. A study in

161 East Kalimantan, Indonesia estimated road construction to account for $14 \%$ of all logging-

162 related carbon emissions (Griscom et al. 2014). These calculations account for the damage

163 that road construction causes to trees adjacent to the corridor (Iskandar et al. 2006, Johns et

164 al. 1996, Jackson et al. 2002). In a Central African study, the biomass recovered through

165 forest regrowth on road tracks abandoned at least 15 years previously accounted for only $6 \%$

166 of the initial amount (Kleinschroth, Healey, Sist, et al. 2016). 
accompanied by the exposure of subsoil, as topsoil is mostly scraped away. Traffic and

machine use cause additional compaction of the soil on the road track (Woodward 1996).

This soil degradation can have important consequences in situ and ex situ. In situ effects are increased bulk density (Donagh et al. 2010, Guariguata \& Dupuy 1997) and reduced soil respiration (Takada et al. 2015), which affect the "soil natural capital", reducing ecosystem services of nutrient retention and cycling, soil formation and primary productivity. Such supporting services are of great importance for vegetation recovery on the road track, thus determining the time duration of many other road impacts. In combination with steep terrain and high rainfall, soil exposure and compaction lead to increased rates of surface water runoff (Douglas 2003, Ziegler et al. 2007), which can result in severe erosion (Clarke \& Walsh 2006, Sidle et al. 2004) and high rates of sediment export (Negishi et al. 2008). Sediment has far reaching ex situ consequences on aquatic habitats in down-slope streams. Greatly enhanced sediment yields have been quantified in Malaysian streams, with levels 14 times higher after logging than before, thus affecting water quality and streamflow through accumulation of sediment and wood debris (Gomi et al. 2006).

After abandonment, road track soils can remain compacted for a long time. In a study in Costa Rica, three out of four roads were still compacted $>10$ years after abandonment (Guariguata \& Dupuy 1997). In Central Africa, abandoned road tracks showed a 36\% decrease in compaction after 15 years but this was still 55\% higher than the level of the adjacent forest (Kleinschroth, Healey, Sist, et al. 2016). Regarding erosion and hydrology it is notable that most studies (with the exception of some reports from Guyana by Steege et al. 1996) have been conducted in South-East Asia, especially Malaysia, where logging 190 intensities are particularly high and the steep terrain is more prone to erosion than in the 191 lowland basins of the Congo and the Amazon rivers. In Sabah, erosion, sediment transport 
192 and landslides show episodic peaks for a long time after logging, depending on the

193 occurrence of extreme weather events (Douglas et al. 1999, Sidle et al. 2006). Early studies

194 that compared sediment yields before and one year after logging showed contradictory results

195 ranging between 3.6 times higher values (Douglas et al. 1992) and no difference at all

196 (Douglas et al. 1993). However, a longer-term study showed that sediment sources 21 years

197 after logging were mainly road-linked (Walsh et al. 2011). The effects of gullying, landslides

198 and collapses of roadfill material contribute to the long-term degradation of soils and

199 watercourses in heavily logged forest areas (Chappell et al. 2004). Road crossings of

200 watercourses can make a large contribution to the sediment load, as bridge abutments are

201 often simply filled with soil that erodes over time as slopes revert back to their angle of

202 repose (Wells 2002). Although sediment production from road surfaces can be reduced by

$20386 \%$ within one year due to establishment of a herb layer (Negishi et al. 2006), recovering

204 vegetation is estimated to take 20 years to reach a sufficient root strength that to prevent

205 landslides on roads in steep terrain (Sidle et al. 2006).

206 Streams are often physically altered wherever they are crossed by logging roads with

207 inadequately constructed or maintained bridges or culverts, thus damming up the stream and

208 creating artificial ponds. A particular problem is caused when road bridges and culverts

209 constructed with logs collapse into streams after road abandonment (Chappell et al. 2004).

210 Recovery of stream water quality can be delayed by many years if sediment is temporarily

211 stored behind channel obstructions and released periodically (Douglas 1999). Obstruction of

212 streams has negative consequences for animal species that depend on fast flowing water and

213 surrounding vegetation that is intolerant of waterlogging, but at the same time it creates new

214 habitats for other species (Schmidt et al. 2015).

215 WEAKENED FOREST RESILIENCE. - Road impacts in forests can extend to a much

216 greater area than just the corridor cleared for road construction. Edge effects may reach far 
217 into the adjacent forest, through desiccation resulting from exposure to wind and higher tree

218 transpiration rates next to the open corridor (Kunert et al. 2015). Such desiccation effects

219 may make an important contribution to the correlation between roads and fire occurrence

220 (Nepstad et al. 1999, Adeney et al. 2009). Tree debris, accumulated at the roadside during

221 road construction, may act as additional fuel for such fires (Laurance \& Useche 2009). Roads

222 may also influence fire regimes through increased fire ignition as a result of human activities

223 that occur in the transportation corridor (Franklin \& Forman 1987, Brando et al. 2014). On

224 the other hand, to fight fires, road access is needed (Francis E. Putz, pers. comm.). Road-

225 related fire-risk also decreases over time as shown by Siegert et al. (2001) for the exceptional

226 fires that raged in Borneo during 1997-98. Sixty-five percent of the area within a $1000 \mathrm{~m}$

227 buffer around recently established logging roads was burned. In contrast, for old logging

228 roads used at least six years earlier, the burnt area was only 16 percent.

229 There are substantial dangers of positive feedbacks between logging roads, fire

230 occurrence and invasions of grasses and lianas (Veldman et al. 2009). In their function as

231 corridors, logging roads can facilitate biological invasions. For example logging trucks have

232 been shown to act as dispersal vectors for exotic grasses in Bolivia (Veldman \& Putz 2010).

233 Also, in South-East Asia, road construction and subsequent swidden agriculture facilitate the

234 invasion of pyrogenic grasses such as the cogon grass, Imperata cylindrica (Putz \& Romero

235 2015). Shrubs have also been reported to spread along logging roads (Padmanaba \& Sheil

236 2014). The establishment of many invasive plants is favoured by the open canopy above the

237 road (Costa \& Magnusson 2002). Consequently the exotic herb species Chromolaena

238 odorata, which is very abundant along open roads in central Africa, disappeared shortly after

239 road abandonment due to growth of taller shading species (Kleinschroth, Healey, Sist, et al.

240 2016). In the Congo Basin, recent El Niño-related fire events showed a clear positive

241 correlation with the abundance of Marantaceae herbs (Verhegghen et al. 2016). These 
242 indigenous herbs show long-lasting high abundance on abandoned logging roads

243 (Kleinschroth, Healey, Sist, et al. 2016), which may explain many (but not all) observed fire

244 outbreaks being located near permanent or recently abandoned logging roads in this region

245 (Verhegghen et al. 2016).

246 Some studies also document negative impacts of animal invasions of forests along

247 roads. The exotic little red fire ant, Wasmannia auropunctata, is reported to spread along

248 logging roads in Gabon, potentially harming the vision of large mammals through its stings

249 (Walsh et al. 2004) and forest anuran communities in Brunei were severely disturbed by the

250 road-facilitated immigration of the predatory greater swamp frog, Limnonectes ingeri

251 (Konopik et al. 2013).

252 WILDLIFE IMPACTS: "LANDSCAPES OF FEAR” AND DEFAUNATION. — Logging roads can

253 have strong impacts on animal population dynamics. While in Australia public roads in

254 rainforests have been associated with high numbers of road kill (Goosem 1997), we did not

255 find any empirical studies that document large numbers of animals killed by logging road

256 traffic. The more important impact of logging roads is that they can fragment animal habitats

257 causing a change in animal behaviour. Open forest roads form a different habitat in terms of

258 microclimate, and may expose animals to potential predators (Thiollay 1997) and a strongly

259 increased likelihood of encounters with hunters. Roads thus present strong peaks in the

260 "landscape of fear" for wildlife (Laundré et al. 2010). Forest specialist and understorey birds

261 in particular are reported to avoid edges created by roads and not to cross them (Lees \& Peres

262 2009, Laurance et al. 2004, Develey \& Stouffer 2001, Laurance 2004). However, in a study

263 by Laurance \& Gomez (2005), radio-tracked birds only refrained from crossing roads when

264 they were in open corridors of $>250 \mathrm{~m}$ width, which is uncommonly wide for logging roads

265 (see above). It is therefore equivocal how far the sheer presence of a logging road inhibits

266 animals of most species from crossing it. A study in Cameroon using track plots filled with 
267 substrates where animals leave traces that can later be associated with a species, suggest that

268 duikers and apes might avoid crossing logging roads (Hoeven 2010). Correlations between

269 reduced animal population densities and proximity to roads have been found to be linked to

270 increased rates of hunting on and around roads (Van Vliet \& Nasi 2008). That hunting is the

271 main factor has also been confirmed through studies comparing roads outside and inside

272 areas where hunting is effectively prevented. Examples are a fenced oil concession (Laurance

273 et al. 2006) and large national parks, where inside the protected areas roads did not affect

274 animal movement patterns, while outside they did (Blake et al. 2008).

275 Unregulated hunting is now imperilling vertebrate species throughout the tropics

276 (Bennett et al. 2002). This has even led to the widespread reporting of "empty" forests

277 (Redford 1992) that look intact from the outside but are actually depleted of major

278 components of their wildlife populations through hunting (Bennett \& Robinson 2000,

279 Poulsen et al. 2011, Laurance et al. 2006). Increased levels of hunting have been noted near

280 logging roads throughout the tropics (Theuerkauf et al. 2001, Laurance et al. 2006, Wong \&

281 Linkie 2013, Hall et al. 1997, Thiollay 1997, Brodie et al. 2015). In Central Africa especially,

282 bushmeat provides the most important source of protein for most forest-dependent

283 communities, who have been hunting for a long time (Nasi et al. 2008). The presence of

284 extensive road networks, however, has allowed the development of a new type of livelihood,

285 that of specialized market hunters. Improved accessibility has extended the reach of the

286 transport chain, which has led to increased quantities of extracted bushmeat being supplied to

287 meet the increasing demand in urbanized areas further away from the forest (Wilkie et al.

288 2000). Logging company employees and other people settling around logging camps are

289 further driving the demand for bushmeat (Bennett \& Gumal 2001). Logging vehicles are

290 frequently used to transport hunters, weapons and game, thus increasing the radius of 
291 defaunation around settlements deeper into the forest (Poulsen et al. 2009, Robinson et al.

292 1999).

293 Little is known about the persistence of hunting impacts after logging road

294 abandonment and for how long transport for commercial hunting remains possible. Hunters

295 on motorcycles might only be able to use logging roads up to 10 years after abandonment due

296 to collapsed bridges and vegetation recovery (Kleinschroth, Healey, Sist, et al. 2016). Roads

297 often continue to be used as footpaths after the end of logging activities, but evidence of the

298 effects of such footpaths on animal populations is ambiguous. Hall et al. (1997) showed that

299 footpaths are avoided by elephants (Loxodonta africana) in Democratic Republic of Congo,

300 while Brodie et al. (2015) showed no effect on mammal abundances of trails on abandoned

301 logging roads.

302 Human disturbance of habitats and animal populations can lead to changes in the

303 overall animal community structure. Changes in species richness and composition have been

304 shown for dung beetles inside road corridors (Hosaka et al. 2014, Yamada et al. 2014) and

305 for nocturnal animals within approximately $30 \mathrm{~m}$ on either side of road edges (Laurance et al.

306 2008). An impact on bird communities has been proposed by Mason (1996) and Thiollay

307 (1997) but could not be confirmed by Develey \& Stouffer (2001). Also, for butterfly

308 communities, no evidence of community changes could be found (Willott et al. 2000).

309 While some roads provide a barrier to animal movement, others function as corridors

310 positively "facilitating" it. Animals may be attracted by roads as they provide connections,

311 orientation and food: Pumas (Puma concolor) and jaguars (Panthera onca) have been

312 identified as "trail walkers" on old logging roads in Belize (Harmsen et al. 2010); african

313 civets (Civettictis civetta) have been reported to use logging roads as preferred pathways and

314 hunting grounds in Africa (Ray \& Sunquist 2001) and leopards (Panthera pardus) are

315 reported to make $20 \%$ of their movements following human paths (Jenny 1996). Also 
316 elephants (Loxodonta africana) feed on secondary vegetation growing on roadsides

317 (Nummelin 1990, Barnes et al. 1997) and after road abandonment, recovering vegetation

318 provides a food source welcomed by gorillas (Gorilla gorilla gorilla) (Matthews \& Matthews

319 2004). Puddles, which frequently develop in ruts and compacted tracks of logging roads,

320 provide surrogate habitats for anuran communities (Ernst et al. 2016).

FOREST CONVERSION IMPACTS. - The issue of human invasion of tropical forest land

322 is central to the issue of whether logged forests become degraded or not (Laurance 2001). In

323 their function as access routes into formerly inaccessible forests, logging roads may not only

324 facilitate illegal logging (Obidzinski et al. 2007) and hunting (Wilkie et al. 1992), but also

325 conversion of forest land to agriculture. The construction of logging roads is often seen as the

326 first step in a sequence of increasing human impact on tropical forests that starts with

327 selective exploitation of forest resources and then leads to forest degradation and eventually

328 deforestation by conversion to agricultural land (Figure 2). In general, conversion of tropical

329 forests to agriculture can be divided into (i) small-scale encroachment through colonization

330 by individual families carrying out swidden agriculture for subsistence or local markets for

331 agricultural products and (ii) large-scale plantations of commercial crops for national or

332 international markets, both in planned (according to legal requirements) and unplanned ways.

333 In Amazonia, a clear correlation has been shown between proximity to a road and

334 deforestation (Laurance et al. 2002). The expansion of the secondary road network (in large

335 parts considered an unofficial or illegal activity; Barber et al. 2014) is often driven by the

336 logging sector (Arima et al. 2005, Perz et al. 2007). Such roads have then been shown to

337 provide entry points to the forest for settlers seeking land (Uhl \& Vieira 1989, Veríssimo et

338 al. 1995). According to remote sensing analyses, logging occurs within $25 \mathrm{~km}$ of detectable

339 roads, and also the probability of logged forests being deforested is four-times higher than for

340 unlogged (Asner et al. 2006). Spatially explicit examples of logging roads in Brazil that have 
341 been unofficially used for colonization are the Transiriri and the Transtutuí roads near Uruará

342 (Arima et al. 2005) and other secondary roads in the state of Pará, such as north of São Félix

343 do Xingu (Mertens et al. 2002). Linear patterns of deforestation along logging roads have

344 also been observed in Central Africa (Mertens \& Lambin 2000) and South-East Asia

345 (Kavanagh et al. 1989), emphasizing that logging roads can open up access to forests for

346 conversion in a wide range of contexts.

$347 \quad$ Not all logging roads necessarily lead to an influx of subsistence farmers (Kummer \&

348 Turner II 1994). Kleinschroth, Healey \& Gourlet-Fleury (2016) showed that only 12\% of

349 roads in a $>100,000 \mathrm{~km}^{2}$ Central African forest area subject to commercial logging remained

350 open for more than 15 years. All other (mostly secondary) logging roads were transient,

351 showing a median persistence of less than four years before recovery of vegetation cover

352 (Kleinschroth et al. 2015). Forest areas in Africa with low human population density are

353 generally not 'opened-up' through conversion to agriculture following logging road

354 construction (Wunder 2005). According to the von Thünen model (Angelsen 2007) it is

355 mostly access to markets that increases the likelihood of forest land being converted to

356 agriculture. Logging operations might not be followed by in-migration at all in remote areas

357 with poor soils that are sparsely populated (Chomitz \& Gray 1996). Putz \& Romero (2015)

358 note that in Indonesia swidden farmers continue to use abandoned logging roads after they

359 have become impassable by vehicles, independently of the proximity to formal markets. The

360 time window for first colonization of forest by small-scale agriculturalists making use of

361 abandoned logging roads may, however, be restricted to the first five years after logging

362 (Walker \& Smith 1993). After that, the recovery of forest biomass makes forest conversion

363 too costly. Generally, logging with its associated road construction cannot in itself be seen as

364 the sole cause of encroachment by agriculturalists, as this often depends on official re-

365 designation of the roads for public use or even large-scale government programs providing 
366 incentives for colonization (Nepstad et al. 2002, Barber et al. 2014, Alvarez \& Naughton-

367 Treves 2003). Governmental infrastructure development plans often simply exploit the

368 opportunity provided by the previous construction of logging roads (Putz \& Romero 2015).

369 In the Amazon logging can lead to feedback loops facilitated by roads, as logging

370 activities attract a growing population and the presence of more people justifies more roads

371 (Fearnside 1985). The attraction of human settlement generally results in an expansion of

372 deforestation or severe forest degradation, eventually making way for the development of

373 large-scale agro-industrial crop and livestock agriculture (Fearnside 1987). Logging reduces

374 the immediately exploitable natural capital of forests, and thus their short-term value,

375 providing an important economic incentive for conversion to cattle pasture, soy-bean or oil-

376 palm crop land in Latin America and South-East Asia (Veríssimo et al. 1995, Uhl \& Vieira

377 1989, Reid \& Bowles 1997, Laurance \& Balmford 2013). Thus, in the absence of appropriate

378 land use planning, road construction can facilitate an expansion of the area converted to other

379 land uses (Chomitz \& Gray 1996). These problems are characteristic of areas where logging

380 and agricultural frontiers are not clearly separated. As frequently observed in Amazonia, in

381 the absence of appropriate planning controls, loggers and ranchers collaborate in road

382 construction for timber exploitation followed by forest conversion to pasture (Schneider et al.

383 2000). Suggested measures to combat conversion of forest along logging roads include

384 communicating evidence to policy makers of the value retained by logged forests for delivery

385 of ecosystem services and conservation of biodiversity (Gaveau et al., 2013; Edwards et al.,

386 2014), providing incentives through certification schemes, and stricter regulation of the

387 granting of logging concessions (Oliveira et al. 2007).

388 The extent to which all or parts of the Trans-Amazonica or other highways in the

389 Brazilian Amazon were initially built as logging roads and subsequently developed into

390 major public roads is not documented. Nonetheless, the vast majority of public roads in 
391 tropical forest areas are likely to have started as logging roads (Francis E. Putz, pers. comm.),

392 providing a lower cost option for increased public access. Loggers (conscious of the large

393 costs involved) build roads where they are needed and where roadbuilding is feasible - the

394 same criteria of feasibility apply to public road building, though the needs may be different.

395 In the available literature, however, increased logging is often described as the consequence

396 rather than the cause of road building and paving (Carvalho et al. 2001, Nepstad et al. 2001,

397 Fearnside 2007, Johns et al. 1996), with the construction of roads providing a subsidy from

398 the government to the timber industry (Uhl et al. 1997). Mertens et al. (2002) advocate the

399 differentiation of numerous processes and actors in the case of Brazil: primary roads are

400 usually built by the state, while secondary road networks are often constructed by loggers,

401 miners or dedicated colonization organisations. Roads built for a certain economic purpose

402 are then regularly abandoned by their initial builders but then improved by colonists.

403 Construction of new roads by large ranchers spontaneously colonising forest areas is the

404 exception (Binswanger 1991) but once the process has started, these roads are sometimes

405 subsequently used and extended by logging companies (Mertens et al. 2002). Uhl et al.

406 (1997) documented these processes for the logging of "terra firme" forest, without forest

407 management plans. Big companies, which have enough capital to invest in constructing their

408 own roads, can operate relatively independently of existing road networks. Their business

409 model is focused on highly selective logging restricted to the most valuable mahogany

410 (Swietenia macrophylla) trees over large areas. In forest areas where such high-value tree

411 species do not occur or have already been logged, this model is not commercially viable, so

412 logging is restricted to areas where there are government-constructed roads. Here, high-

413 intensity logging is often carried out by less-well-capitalised, small-scale local enterprises,

414 followed by individuals using only a chainsaw who take the leftover trees. This cascade of 
415 uncontrolled exploitation, resulting from the initial road construction, generally leads to

416 severe forest degradation and may pave the way for subsequent conversion to agriculture.

417 Logging road impacts also have an anthropological dimension. For Amazonia,

418 concern has arisen that logging roads could provide unwanted access by outsiders to the land

419 of indigenous communities, thus destroying their traditional way of life (Veríssimo et al.

420 1995, Uhl \& Vieira 1989). In contrast, however, there is a more widespread (but often

421 neglected) demand from rural communities in tropical forest areas for improved access

422 through new or better roads. In Central Africa, for example, Tiani et al. (2005) reported a

423 positive perception by local communities of new road connections, facilitating access to

424 health care and education. Protecting the health of people living along roads does, however,

425 require the management of road surface quality in a way that limits the risk of respiratory

426 diseases from dust raised by heavy logging vehicles (Cerutti et al. 2014).

ROAD PLANNING AS A COMPONENT OF SUSTAINABLE FOREST MANAGEMENT. — Road

428 construction is one of the most costly components of selective logging operations (Holmes et

429 al. 2002, Medjibe \& Putz 2012). Therefore, investment in road construction and management

430 depends on the capital of logging companies (Gaveau et al. 2009). Best practice engineering

431 guidelines for logging road construction in tropical forests have been published since the

432 1950's (reviewed by Kleinschroth, Gourlet-Fleury, et al. 2016). There have been few notable

433 developments in road engineering over this period, despite increased concern about the need

434 to reduce negative environmental impacts. The bigger issue is that the existing best practice

435 recommendations are rarely implemented, throughout the tropics (Putz et al. 2000).

436 A landmark publication setting out recommendations for improved road planning,

437 construction and maintenance is the FAO model code of forest harvesting practice (Dykstra

438 \& Heinrich 1996), which played a crucial role in the development of reduced-impact logging

439 (RIL) guidelines (Pinard et al. 1995). The need for effective planning of road networks before 
440 they are constructed, in order to reduce residual stand damage, loss of biomass and damage to

441 soil and watercourses, is a key component of RIL (Putz et al. 2008, Sist 2000). One

442 component of this planning is to minimize road length density by optimizing the layout to

443 reach the resource via the shortest path (Gullison \& Hardner 1993, Picard et al. 2006).

444 However, there is a potential trade-off between roads that are short and straight and those that

445 are fitted to the topography to avoid steep slopes and the buffer zones of water courses

446 (Negishi et al. 2008, Le Ray 1956), and even avoid large individual trees that are planned to

447 be retained (Malcolm \& Ray 2000). Overall, carefully planned road networks have been

448 shown to reduce forest damage by $40 \%$ compared with unplanned existing practice (Johns et

449 al. 1996). Planning road networks that best combine minimisation of environmental damage

450 with economic efficiency requires high quality engineering based on accurate topographical

451 and edaphic/geotechnical information. Generally-available remotely-sensed imagery is not

452 sufficient for accurate road planning, but imagery that penetrates the forest canopy down to

453 ground level (in particular LiDAR) offers the prospect of a step-change improvement (Putz \&

454 Romero 2015).

455 The width of road corridors from which trees are cleared is another important

456 dimension for limiting environmental impact (Sist 2000). Forest canopy cover is commonly

457 cleared on both sides of the road to increase the rate of sun drying of the road surface after

458 rain (Sessions 2007). However, depending on road orientation the width required to

459 effectively achieve this can be quite narrow due to the high angle of the sun in the tropics

460 (Wells 2002). The better a road is maintained and drained (e.g. through a parabolic camber

461 throughout) the smaller can be the canopy opening needed to keep the surface sufficiently dry

462 (Allouard 1954). In areas with notable rainfall seasonality restricting log extraction from core

463 forest areas to the dry season would allow the use of low maintenance roads under a closed

464 canopy. Reducing the width of the road corridor does increase the risk of vehicle collisions 
465 with wildlife, therefore it should be accompanied by enforced speed limitations (Sessions

466 2007). Canopy bridges (achieved by large trees whose crowns meet across the road being

467 retained unfelled) and infrastructure installed to increase the connectivity of animal habitats

468 (e.g. tunnels below the road surface) are also recommended as a means of increasing the

469 potential for wildlife to safely cross road corridors (Goosem 2007).

470 Reducing the impacts of roads on forest biodiversity as a component of sustainable

471 forest management requires the implementation of measures to prevent increased hunting and

472 agricultural colonization following logging (Laurance 2001). Control of access to roads

473 during and after logging is crucial (Bicknell et al. 2015), and requires both guarded barriers at

474 strategic points in the permanent road network and the closure of logging roads (= "putting

475 roads to bed") after harvest (Mason \& Putz 2001, Applegate et al. 2004). The corridor of

476 closed roads can be used to promote forest recovery, e.g. enrichment planting or other

477 measures to promote the natural regeneration of timber trees (Kleinschroth, Healey, Sist, et

478 al. 2016). Such tree plantations may also provide a psychological barrier against land

479 colonization by swidden farmers (Putz \& Romero 2015). Consideration should, nonetheless,

480 be given to reopening roads that had been closed at the end of the previous logging operation

481 for subsequent harvest operations in order to avoid the construction of new roads in the same

482 area, or as a cost-effective alternative to opening up new forest areas for logging (Figure 3,

483 Kleinschroth, Healey \& Gourlet-Fleury 2016). If forest managers focus their management

484 activities around a well-planned network of logging roads they can reduce both costs and

485 unintended subsequent impacts (Putz \& Romero 2015).

486 To achieve sustainable forest management, companies that hold logging concessions

487 should be held responsible for careful management of the quality and accessibility of their

488 road networks. There is an argument that the infrastructure of tropical production forests

489 should be managed like that of temperate forests, with a well-planned network of maintained 
490 permanent roads for management access (Francis E. Putz, pers. comm.). Here, roads are used

491

492

493

494

495

496

497

498

499

500

501

502

503

504

505

506

507 not just during logging operations but also for interim monitoring, fire control and

silvicultural interventions such as enrichment planting and thinning. These advantages,

however, need to be weighed up against the risks of access for illegal hunting and

encroachment that is often unregulated due to the institutional constraints in many tropical

countries. Weak governance and lack of law enforcement also means that we cannot rely on

protected forest areas to achieve conservation objectives. Therefore it is crucial to maximize

the conservation value of the surrounding matrix of logged forest (Clark et al. 2009) by

keeping it free of permanently accessible road that cause the fragmentation of forest habitat

and a reduction in roadless space. The strategic planning of where to place permanent and

temporary roads in the overall forest landscape is therefore crucial for achieving the best

compromise between retaining access for ongoing forest management, while minimising

long-term fragmentation and degradation in the highest priority areas for biodiversity

conservation (Kleinschroth et al. 2017). The debate about "land sharing versus land sparing"

also applies in the context of tropical timber production. The question here is in which areas

should timber be harvested through separate one-off operations using temporary road

infrastructure versus installing permanent road infrastructure (with its greater costs of initial

capital and ongoing maintenance) to allow the forest to be managed for continuing higher

timber yields, i.e. "sustainable intensification" (Putz \& Ruslandi 2015). Such intensification

in appropriate areas could help to ensure the protection of intact forests and roadless areas

elsewhere, thus achieving the goal of land-sparing-logging (Edwards et al. 2014), as

anticipated by the scenarios of Healey et al. (2000). For such protection of intact forests to be

effective, region-wide landscape planning would be necessary.

LOGGING ROADS AS FOREST HABITAT COMPONENTS. —Forest road corridors can be associated with five elementary functions: filter or barrier, conduit, source, sink and habitat 
515 (Forman 2003). The habitat type provided by logging roads is otherwise relatively rare in

516 tropical forests (except along river channels or on very steep slopes subject to landslides),

517 with its bare soil and greatly elevated light availability, which have been shown to increase

518 leaf and fruit production in woody plants growing adjacent to road corridors (Johns 1988).

519 Abandoned logging roads can even contribute to forest habitat diversity, which can increase

520 some components of biodiversity, as shown for temperate forests (Coffin 2007). Wherever

521 vegetation establishment is not prevented by severe soil degradation or continued road use,

522 there is good potential for gradual recovery of ecosystem services, including provision of

523 timber following tree regeneration. In regions with low intensity timber harvesting, enhanced

524 levels of regeneration of light-demanding timber species have been observed on abandoned

525 logging roads (Fredericksen \& Mostacedo 2000, Nabe-Nielsen et al. 2007, Swaine \&

526 Agyeman 2008, Kleinschroth, Healey, Sist, et al. 2016). The road edge zone on either side of

527 the track, from which trees are cleared during road construction, is a particularly suitable

528 microhabitat for recruitment of timber species (Guariguata and Dupuy, 1997; Doucet, 2004).

529 In contrast, in areas where soils are vulnerable to severe soil compaction or capping of the

530 surface, especially where forests are subject to high-intensity timber harvesting such as the

531 dipterocarp forests of South-East Asia, reduced levels of tree regeneration have been reported

532 on abandoned roads and skid trails (Pinard et al., 1996, 2000; Zang and Ding, 2009). Here,

533 plants that can colonise degraded soils, such as certain fern species, may play an important

534 role in ameliorating soil conditions and facilitating gradual forest recovery through vegetation

535 succession. In their study in Peninsular Malaysia, Negishi et al. (2006) estimated that it

536 would take up to 40 years for ferns to ameliorate substrate conditions sufficiently to enable

537 taller plant species to establish a canopy that out-shades the ferns. Generally, the composition

538 of vegetation recovering on abandoned logging roads may differ from that of old-growth 
539 forest for a long time, even if tree species diversity can reach comparable levels after 15 years

540 (Kleinschroth, Healey, Sist, et al. 2016, but see Guariguata \& Dupuy 1997).

541 OUTLOOK. - We have identified major knowledge gaps concerning long-term

542 impacts of logging roads. While there have been many studies of the immediate impacts of

543 logging roads on animal community composition and movement, little is known about how

544 this affects wildlife populations over the long-term. Much depends on how the barrier-effect

545 and road-related threats such as poaching develop over time, and their impact on genetic

546 diversity and exchange within populations. Given the practical limitations of field studies and

547 the physical limits of remote sensing information, other innovative technologies should be

548 tested for inclusion in scientific studies. There is already a rapid expansion in the use of

549 camera traps and other electronic animal tracking devices in tropical forests (Harmsen et al.

550 2010, Vanthomme et al. 2013), which could be deployed in the study of road impacts. An

551 example of more innovative approaches is the Rainforest Connection project

552 (https://rfcx.org/) that places solar-powered smartphones equipped with software that can

553 filter different audio-signals in rainforest canopies. These devices are programmed to send an

554 alert when they record the sound of motors such as those of chainsaws or motorbikes,

555 indicating illegal activities, and they could be used as a cost-effective method of monitoring

556 poaching.

557 The most common way to assess human impact on tropical forests over a large scale

558 is by using roads as indicators (Laporte et al. 2007, Asner et al. 2009, Lewis et al. 2015).

559 However, this approach does not differentiate between types of roads, although they can

560 differ hugely in the severity and duration of impact that they indicate. Therefore, more effort

561 is needed to understand and disentangle the impacts of roads depending on their location and

562 connectivity in the overall network, the purposes that they are used for, how they are

563 managed and maintained, and for how long they persist. There is a lack of quantification of 
564 the proportion of roads that have enabled long-term human encroachment versus those that

565 have not, becoming impassable due to washouts of bridges and culverts, and recolonization

566 by forest vegetation. For roads that have led to long-term forest degradation or conversion to

567 agriculture, it would be important for forest policy to know what proportion were initially

568 built for logging versus other purposes. This evidence would enable testing of whether road

569 construction for logging invariably leads to subsequently illegal forest exploitation. It would

570 also indicate whether and where there is a need to focus actions to prevent this occurring, in

571 places where legal logging is allowed to continue.

572 CONCLUSIONS. - The indirect impacts of logging roads on occurrence of fire,

573 deterioration of water quality, conversion to agriculture and increased hunting are much more

574 severe than the direct impacts of road construction and planned use on forest cover, soil and

575 wildlife, as these are limited in persistence and in the surface area that they affect. To reduce

576 the subsequent indirect impacts, road access management is therefore crucial. For many

577 tropical countries, however, it remains questionable how successful the enforcement of

578 access restrictions can be, given the high demands for bushmeat and agricultural land. One

579 solution to this problem is to intensify road construction and timber harvesting in suitable

580 areas with high production potential, while sparing other areas of high conservation value

581 from any new road construction.

582 In the nexus of roads, hunting and deforestation it is generally difficult to determine if

583 roads are endogenous or exogenous factors (Lambin et al. 2003). The question is, do roads

584 affect just the precise location or also the overall quantity of forest conversion and hunting?

585 So far, it seems that the construction of roads reduces the costs of such activities, thus making

586 them affordable for more people. It remains unclear, however, what alternative sources of

587 nutrition and livelihood are available for growing rural populations, and which productive

588 land can be used to provide them. Much depends on the direction of transformations in 
589 society and how people's interaction with their natural environment changes, including forest

590 conversion planned by governments. Poor governance, human population growth, migration

591 and dependence on markets (from local to international) make this direction very hard to

592 predict.

593 Roads are becoming an increasingly common component of tropical forests around

594 the world. Given the great importance of logged forests for biodiversity conservation and

595 carbon storage, and the high potential risks associated with the presence of roads, large-scale

596 road planning needs to be placed near the top of the forest policy agenda. Monitoring the

597 spatio-temporal dynamics of roads in tropical forests will provide crucial evidence for the

598 goal of "development without destruction" (Lewis et al. 2015) through large-scale landscape

599 planning. Its implementation is likely to require much more effective management of the

600 accessibility of forest roads than is generally the case currently.

601

602

\section{ACKNOWLEDGMENTS}

603 We are grateful to two anonymous reviewers and Jack Putz, who provided very

604 detailed and constructive comments that greatly helped to improve the manuscript.

605

\section{DATA AVAILABILITY STATEMENT}

Library entries for the full pre-selected literature database will be made available on DRYAD digital repository in *.bib, *.ris and *.xml formats.

\section{LITERATURE CITED}

Adeney, J. M., N. L. Christensen, and S. L. PIMM. 2009. Reserves protect against deforestation fires in the Amazon. PLoS One 4: DOI: 10.1371/journal.pone.0005014.

612 AhMED, S. E., R. M. EWERS, and M. J. SMITH. 2013. Large scale spatio-temporal patterns of road 613 development in the Amazon rainforest. Environ. Conserv. 41: 253-264.

614 Ahmed, S. E., C. M. SOUZA, J. Riberio, and R. M. EwERS. 2013. Temporal patterns of road network 615 development in the Brazilian Amazon. Reg. Environ. Chang. 13: 927-937. 
ALVAREZ, N. L., and L. NAUGHTON-TREVES. 2003. Linking national agrarian policy to deforestation in the Peruvian Amazon: a case study of Tambopata, 1986-1997. Ambio 32: 269-274.

Angelsen, A. 2007. Forest cover change in space and time: Combining the von Thünen and forest transition theories. World Bank Policy Res. Work. Pap. 4117: 1-43.

ApPlegate, G., F. E. PUTZ, and L. K. SNOOK. 2004. Who pays for and who benefits from improved timber harvesting practices in the tropics? Lessons learned and information gaps. CIFOR, Bogor, Indonesia.

Arevalo, B., J. Valladarez, S. Muschamp, E. Kay, A. Finkral, A. Roopsind, and F. E. Putz. 2016. Effects of reduced-impact selective logging on palm regeneration in Belize. For. Ecol. Manage. 369: 155-160.

ARIMA, E. Y., R. T. WALKER, S. G. PerZ, and M. CALDAS. 2005. Loggers and forest fragmentation: behavioral models of road building in the Amazon basin. Ann. Assoc. Am. Geogr. 95: 525-541.

Arima, E. Y., R. T. WAlKer, M. Sales, C. SouZA, and S. G. PerZ. 2008. The fragmentation of space in the Amazon Basin: emergent road networks. Photogramm. Eng. Remote Sens. 74: 699709.

Asner, G., M. Keller, R. PereirA, and J. ZWEedE. 2002. Remote sensing of selective logging in Amazonia: Assessing limitations based on detailed field observations, Landsat ETM+, and textural analysis. Remote Sens. Environ. 80: 483-496.

Asner, G. P., E. N. Broadbent, P. J. C. Oliveira, M. Keller, D. E. KnapP, and J. N. M. Silva. 2006. Condition and fate of logged forests in the Brazilian Amazon. Proc. Natl. Acad. Sci. U. S. A. 103: $12947-50$.

Asner, G. P., T. K. Rudel, T. M. Aide, R. DEFries, and R. EMERSON. 2009. A contemporary assessment of change in humid tropical forests. Conserv. Biol. 23: 1386-95.

BARBer, C. P., M. A. Cochrane, C. M. SouZA, and W. F. LAURANCE. 2014. Roads, deforestation, and the mitigating effect of protected areas in the Amazon. Biol. Conserv. 177: 203-209.

Barnes, R. F. W., K. Beardsley, F. Michelmore, K. L. Barnes, M. P. T. Alers, and A. Blom. 1997. Estimating forest elephant numbers with dung counts and a geographic information system. J. Wildl. Manage. 61: 1384-1393.

BENNETT, E. L., and M. T. GUMAL. 2001. The interrelationships of commercial logging, hunting, and wildlife in Sarawak: Recommendations for Forest Management. In The Cutting Edge: Conserving Wildlife in Logged Tropical Forests. pp. 359-374, Columbia University Press.

Bennett, E. L., E. J. Milner-Gulland, M. BAKarR, H. E. Eves, J. G. Robinson, and D. S. WILKIE. 2002. Hunting the world's wildlife to extinction. Oryx 36: 328-329.

BENNETT, E. L., and J. G. RoBINSON. 2000. Hunting of wildlife in tropical forests - implications for biodiversity and forest peoples. The World Bank Environmental Department, Washington, D.C.

Bicknell, J. E., D. L. A. GAVEAU, Z. G. DAVIS, and M. J. StRUEBIG. 2015. Saving logged tropical forests: closing roads will bring immediate benefits. Front. Ecol. Environ. 13: 73-74.

BINSWANGER, H. P. 1991. Brazilian policies that encourage deforestation in the Amazon. World Dev. 19: 821-829.

Blake, S., S. L. DeEm, S. StrindBerg, F. MAisels, L. Momont, I.-B. Isia, I. DouglasHAMILTON, W. B. KARESH, and M. D. KOCK. 2008. Roadless wilderness area determines forest elephant movements in the Congo Basin. PLoS One 3: e3546.

Blaser, J., A. SARre, D. PoOre, and S. Johnson. 2011. Status of tropical forest management 2011. ITTO Technical Series No 38. International Tropical Timber Organization, Yokohama, Japan. 
BRANDÃO, A. O., and C. M. SOUZA. 2006. Mapping unofficial roads with Landsat images: a new tool to improve the monitoring of the Brazilian Amazon rainforest. Int. J. Remote Sens. 27: 177-189.

662

663

664

665

666

667

668

669

670

671

672

673

674

675

676

677

678

679

680

681

682

683

684

685

686

687

688

689

690

691

692

693

694

695

696

697

698

699

700

701

702

703

Brando, P. M., J. K. Balch, D. C. Nepstad, D. C. Morton, F. E. Putz, M. T. Coe, D. Silvério, M. N. Macedo, E. a Davidson, C. C. Nóbrega, A. Alencar, and B. S. SoAres-Filho. 2014. Abrupt increases in Amazonian tree mortality due to drought-fire interactions. Proc. Natl. Acad. Sci. 111: 6347-52.

Brodie, J. F., A. J. Giordano, E. F. Zipkin, H. Bernard, J. Mohd-Azlan, and L. AmbU. 2015. Correlation and persistence of hunting and logging impacts on tropical rainforest mammals. Conserv. Biol. 29: 110-121.

Carvalho, G., A. C. Barros, P. Moutinho, and D. Nepstad. 2001. Sensitive development could protect Amazonia instead of destroy it. Nature 409: 131.

Cerutti, P. ., G. Lescuyer, R. Tsanga, S. . Kassa, P. . Mapangou, E. . Mendoula, A. . MisSAMBA-LOLA, R. NASI, P. P. . ECKEBIL, and R. Y. YEMBE. 2014. Social impacts of the Forest Stewardship Council certification. An assessment in the Congo basin. Occasional Paper 103. CIFOR, Bogor, Indonesia.

Chappell, N. A., I. Douglas, J. M. HANAPI, and W. TYCH. 2004. Sources of suspended sediment within a tropical catchment recovering from selective logging. Hydrol. Process. 18: 685-701.

CHOMITZ, K. M., and D. A. GRAY. 1996. Roads, land use, and deforestation: a spatial model applied to Belize. World Bank Econ. Rev. 10: 487-512.

Clark, C. J., J. R. Poulsen, R. MAlonga, and P. W. ElKan. 2009. Logging concessions can extend the conservation estate for Central African tropical forests. Conserv. Biol. 23: 1281-93.

ClARKe, M. A., and R. P. D. WALSH. 2006. Long-term erosion and surface roughness change of rainforest terrain following selective logging, Danum Valley, Sabah, Malaysia. Catena 68: 109-123.

Clements, G. R., A. J. Lynam, D. Gaveau, W. L. Yap, S. Lhota, M. Goosem, S. LaURAnCe, and W. F. LAURANCE. 2014. Where and how are roads endangering mammals in Southeast Asia's forests? PLoS One 9: e1 15376.

Coffin, A. W. 2007. From roadkill to road ecology: A review of the ecological effects of roads. J. Transp. Geogr. 15: 396-406.

Costa, F., and W. MAGNUSSON. 2002. Selective logging effects on abundance, diversity, and composition of tropical understory herbs. Ecol. Appl. 12: 807-819.

Curran, L. M., S. N. TrigG, a K. McDonald, D. Astiani, Y. M. Hardiono, P. Siregar, I. CANIAGO, and E. KASISCHKE. 2004. Lowland forest loss in protected areas of Indonesian Borneo. Science 303: 1000-1003.

DeVELEY, P. F., and P. C. STOUFFER. 2001. Effects of roads on movements by understory birds in mixed-species flocks in central Amazonian Brazil. Conserv Biol 15: 1416-1422.

Donagh, P. MaC, L. Rivero, J. Garibaldi, M. ALVEZ, and P. CorTez. 2010. Effects of selective harvesting on traffic pattern and soil compaction in a subtropical forest in Guarani, Misiones, Argentine. Sci. For. 2472: 115-124.

DOUGLAS, I. 1999. Hydrological investigations of forest disturbance and land cover impacts in SouthEast Asia: a review. Philos. Trans. R. Soc. Lond. B. Biol. Sci. 354: 1725-1738.

Douglas, I. A. N. 2003. Predicting road erosion rates in selectively logged tropical rain forests. In D. de Boer, W. Froehlich, T. Mizuyama, and A. Pietroniro (Eds.) Erosion Prediction in Ungauged Basins: Integrating Methods and Techniques. pp. 199-205, IAHS Press, Wallingford, UK.

Douglas, I., K. Bidin, G. Balamurugan, N. a Chappell, R. P. WAlsh, T. GReER, and W. Sinun. 
1999. The role of extreme events in the impacts of selective tropical forestry on erosion during harvesting and recovery phases at Danum Valley, Sabah. Philos. Trans. R. Soc. Lond. B. Biol. Sci. 354: 1749-1761.

DOUGLAS, I., T. GREER, B. KAWI, and S. WAIDI. 1993. Impact of roads and compacted ground on post-logging sediment yield in a small drainage basin, Sabah, Malaysia. Hydrology of warm humid regions. IAHS Publ. 216: 213-218.

Douglas, I., T. Spencer, T. Greer, K. Bidin, W. Sinun, and W. W. Meng. 1992. The impact of selective commercial logging on stream hydrology, chemistry and sediment loads in the Ulu Segama rain forest, Sabah, Malaysia. Philos. Trans. R. Soc. London. Ser. B Biol. Sci. 335: 397 LP-406.

DULAC, J. 2013. Global Land Transport Infrastructure Requirements: Estimating road and railway infrastructure capacity and costs to 2050. International Energy Agency, Paris.

DurRiEu DE MAdRon, L., B. FonTEZ, and B. DiPAPOUNDJI. 2000. Dégâts d'exploitation et de débardage en fonction de l'intensité d'exploitation en forêt dense humide d'Afrique Centrale. Bois Forêts des Trop. 264: 57-60.

DYKSTRA, D. P., and R. HEINRICH. 1996. FAO model code of forest harvesting practice. FAO, Rome.

Edwards, D. P., J. J. Gilroy, P. WoOdCock, F. A. Edwards, T. H. LARSEN, D. J. R. ANDrews, M. A. DeRhé, T. D. S. DocherTy, W. W. HSU, S. L. Mitchell, T. OTA, L. J. Williams, W. F. LAURANCE, K. C. HAMER, and D. S. WILCOVE. 2014. Land-sharing versus land-sparing logging: reconciling timber extraction with biodiversity conservation. Glob. Chang. Biol. 20: 183-91.

Edwards, D. P., T. H. Larsen, T. D. S. Docherty, F. a Ansell, W. W. Hsu, M. A Derhé, K. C. HAMER, and D. S. WILCOVE. 2011. Degraded lands worth protecting: the biological importance of Southeast Asia's repeatedly logged forests. Philos. Trans. R. Soc. Biol. Sci. 278: 82-90.

ERnst, R., M. Hölting, K. Rodney, V. BenN, R. Thomas-CAesar, and M. Wegmann. 2016. A frog's eye view: logging roads buffer against further diversity loss. Front. Ecol. Environ. 14: 353-355.

ESTĖVE, J. 1983. La destruction du couvert forestier consécutive à l'exploitation forestière de bois d'ouvre en forêt dense tropicale humide africaine ou américaine. Bois Forêts des Trop. 201: 7784 .

FAO. 1995. Forest harvesting case study 7: Forest harvesting in natural forests of the Congo. R. Scharpenberg (Ed.). Food and Agriculture Organization of the United Nations, Rome, Italy.

FEARNSIDE, P. M. 1985. Deforestation and decision-making in the development of brazilian amazonia. Interciencia 10: 243-247.

FEARNSIDE, P. M. 1987. Causes of deforestation in the Brazilian Amazon. In R. F. Dickinson (Ed.) The Geophysiology of Amazonia: Vegetation and Climate Interactions. pp. 37-61, John Wiley $\&$ Sons, New York.

FEARNSIDE, P. M. 2007. Brazil's Cuiabá- Santarém (BR-163) highway: The environmental cost of paving a soybean corridor through the Amazon. Environ. Manage. 39: 601-614.

FeldPAusCh, T. R., S. JiRKA, C. A. M. PASSOS, F. JASPER, and S. J. RiHA. 2005. When big trees fall: Damage and carbon export by reduced impact logging in southern Amazonia. For. Ecol. Manage. 219: 199-215.

FORMAN, R. T. T. 2003. Road ecology: science and solutions. Island Press, Washington, D.C.

FRANKLIN, J. F., and R. T. T. FORMAN. 1987. Creating landscape patterns by forest cutting: Ecological consequences and principles. Landsc. Ecol. 1: 5-18. 
FREDERICKSEN, T. S., and B. MostACEDO. 2000. Regeneration of timber species following selection logging in a Bolivian tropical dry forest. For. Ecol. Manage. 131: 47-55.

Gaveau, D. L. A., S. Sloan, E. Molidena, H. Yaen, D. Sheil, N. K. Abram, M. Ancrenaz, R. NASI, M. QUINONES, N. WiElAARD, and E. MEIJAARD. 2014. Four decades of forest persistence, clearance and logging on Borneo K. Bawa (Ed.). PLoS One 9: e101654.

Gaveau, D. L. A, S. Wich, J. Epting, D. Juhn, M. KanNinen, and N. Leader-Williams. 2009. The future of forests and orangutans (Pongo abelii) in Sumatra: predicting impacts of oil palm plantations, road construction, and mechanisms for reducing carbon emissions from deforestation. Environ. Res. Lett. 4: 19.

Gideon Neba, S., M. Kanninen, R. EbA'A Atyi, and D. J. Sonwa. 2014. Assessment and prediction of above-ground biomass in selectively logged forest concessions using field measurements and remote sensing data: Case study in South East Cameroon. For. Ecol. Manage. 329: 177-185.

Gomi, T., R. C. Sidle, S. Noguchi, J. N. Negishi, A. R. NiK, and S. SASAKI. 2006. Sediment and wood accumulations in humid tropical headwater streams: Effects of logging and riparian buffers. For. Ecol. Manage. 224: 166-175.

Goosem, M. 1997. Internal fragmentation: the effects of roads, highways, and powerline clearings on movements and mortality of rainforest vertebrates. In W. F. Laurance and R. O. Bierregaard (Eds.) Tropical forest remnants, ecology, management, and conservation of fragmented communities. pp. 241-255, University of Chicago Press.

Goosem, M. 2007. Fragmentation impacts caused by roads through rainforests. Curr. Sci. 93: 15871595.

GRISCOM, B., P. ElLIS, and F. E. PUTZ. 2014. Carbon emissions performance of commercial logging in East Kalimantan, Indonesia. Glob. Chang. Biol. 20: 923-37.

GuARIguATA, M. R., and J. M. DUPUY. 1997. Forest regeneration in abandoned logging roads in lowland Costa Rica. Biotropica 29: 15-28.

GULLISON, R. E., and J. J. HARDNER. 1993. The effects of road design and harvest intensity on forest damage caused by selective logging: empirical results and a simulation model from the Bosque Chimanes, Bolivia. For. Ecol. Manage. 59: 1-14.

Hall, J. S., B. InOgWabini, E. A. Williamson, I. Omari, C. SikubWabo, and L. J. T. White. 1997. A survey of elephants (Loxodonta africana) in the Kahuzi-Biega National Park lowland sector and adjacent forest in eastern Zaire. Afr. J. Ecol. 35: 213-223.

HARMSEn, B. J., R. J. Foster, S. SiLver, L. Ostro, and C. P. DoncASTER. 2010. Differential use of trails by forest mammals and the implications for camera trap studies, a case study from Belize, Central America. Biotropica 42: 126-133.

Hawthorne, W. D., C. A. M. Marshall, M. A. Juam, and V. K. Agyeman. 2011. The Impact of Logging Damage on Tropical Rainforests , their Recovery and Regeneration an Annotated Bibliography. Oxford Forestry Institute, Oxford.

HeAley, J. R., C. Price, and J. TAY. 2000. The cost of carbon retention by reduced impact logging. For. Ecol. Manage. 139: 237-255.

HOEVEN, C. VAN DER. 2010. Roadside conditions as predictor for wildlife crossing probability in a Central African rainforest. Afr. J. Ecol. 48: 368-377.

Holmes, T. P., G. M. Blate, J. C. Zweede, R. Pereira, P. Barreto, F. Boltz, and R. Bauch. 2002. Financial and ecological indicators of reduced impact logging performance in the eastern Amazon. For. Ecol. Manage. 163: 93-110.

HosaKa, T., M. NiInO, M. Kon, T. OChI, T. YAMADA, C. Fletcher, and T. OKUDA. 2014. Effects 
of logging road networks on the ecological functions of dung beetles in Peninsular Malaysia. For. Ecol. Manage. 326: 18-24.

HUNTINGDON, B. E. 2011. Confronting publication bias in marine reserve meta-analyses. Front. Ecol. Environ. 9: 375-376.

ISKANDAR, H., L. K. SNOOK, T. TOMA, K. G. MACDiCKEN, and M. KANNINEN. 2006. A comparison of damage due to logging under different forms of resource access in East Kalimantan, Indonesia. For. Ecol. Manage. 237: 83-93.

JaCKSON, S. M., T. S. FrederiCKSEN, and J. R. MALCOLM. 2002. Area disturbed and residual stand damage following logging in a Bolivian tropical forest. For. Ecol. Manage. 166: 271-283.

JENNY, D. 1996. Spatial organization of leopards Panthera pardus in Taï National Park, Ivory Coast: is rainforest habitat a "tropical haven"? J. Zool. 240: 427-440.

JOHNS, A. D. 1988. Effects of "selective" timber extraction on rain forest structure and composition and some consequences for frugivores and folivores. Biotropica 20: 31-37.

JOHNS, J. S., P. BARRETO, and C. UHL. 1996. Logging damage during planned and unplanned logging operations in the eastern Amazon. For. Ecol. Manage. 89: 59-77.

KaVAnAGH, M., A. A. RAHIM, and C. J. HAils. 1989. Rainforest conservation in Sarawak an international policy for WWF. WWF Malaysia and WWF International, Kuala Lumpur, Gland.

Kleinschroth, F., S. Gourlet-Fleury, P. Sist, V. Gond, and J. R. Healey. 2016. Logging roads in tropical forests: Synthesis of literature written in French and English highlights environmental impact reduction through improved engineering. Bois Forêts des Trop. 328: 13-26.

Kleinschroth, F., S. Gourlet-Fleury, P. Sist, F. Mortier, and J. R. Healey. 2015. Legacy of logging roads in the Congo Basin: How persistent are the scars in forest cover? Ecosphere 6: 64.

Kleinschroth, F., J. R. Healey, and S. Gourlet-Fleury. 2016. Sparing forests in Central Africa: re-use old logging roads to avoid creating new ones. Front. Ecol. Environ. 14: 9-10.

Kleinschroth, F., J. R. Healey, S. Gourlet-Fleury, F. Mortier, and R. S. Stoica. 2017. Effects of logging on roadless space in intact forest landscapes of the Congo Basin. Conserv. Biol. 31: 469-480.

Kleinschroth, F., J. R. HeAley, P. Sist, F. Mortier, and S. Gourlet-Fleury. 2016. How persistent are the impacts of logging roads on Central African forest vegetation? J. Appl. Ecol. 53: 1127-1137.

KONOPIK, O., K.-E. LINSENMAIR, and T. U. GRAFE. 2013. Road construction enables establishment of a novel predator category to resident anuran community: a case study from a primary lowland Bornean rain forest. J. Trop. Ecol. 30: 13-22.

KumMER, D. M., and B. L. TURNER II. 1994. The human causes of deforestation in Southeast Asia. Bioscience 44: 323-328.

Kunert, N., L. M. T. Aparecido, N. Higuchi, J. DOS SAntos, and S. TRUMBORE. 2015. Higher tree transpiration due to road-associated edge effects in a tropical moist lowland forest. Agric. For. Meteorol. 213: 183-192.

LAMBIN, E. F., H. J. GEIST, and E. LEPERS. 2003. Dynamic of land-use and land-cover change in tropical regions. Annu. Rev. Environ. Resour. 28: 205-241.

LAPORTE, N. T., J. A StABACH, R. Grosch, T. S. Lin, and S. J. GoETZ. 2007. Expansion of industrial logging in Central Africa. Science (80-. ). 316: 1451.

LAUNDRÉ, J. W., L. HERNANDEZ, and W. J. RIPPLE. 2010. The landscape of fear: ecological 
implications of being afraid. Open Ecol. J. 3: 1-7.

837

LAURANCE, S. G. W. 2004. Responses of understory rain forest birds to road edges in central Amazonia. Ecol. Appl. 14: 1344-1357.

LAURANCE, S. G. W., and M. S. GOMEZ. 2005. Clearing width and movements of understory rainforest birds. Biotropica 37: 149-152.

LAURANCE, S. G. W., P. C. STOUfFer, and W. F. LAURANCE. 2004. Effects of road clearings on movement patterns of understory rainforest birds in Central Amazonia. Conserv. Biol. 18: 10991109.

LAURANCE, W. F. 2001. Tropical logging and human invasions. Conserv. Biol. 15: 4-5.

Laurance, W. F., A K. M. Albemaz, G. Schroth, P. M. Fearnside, S. Bergen, E. M. VENTICINQUE, and C. DA COSTA. 2002. Predictors of deforestation in the Brazilian Amazon. J. Biogeogr. 29: 737-748.

LAURANCE, W. F., and A. BALMFORD. 2013. A global map for road building. Nature 495: 308-309.

laurance, W. F., G. R. Clements, S. Sloan, C. S. O’Connell, N. D. Mueller, M. Goosem, O. Venter, D. P. Edwards, B. Phalan, A. Balmford, R. Van Der Ree, and I. B. Arrea. 2014. A global strategy for road building. Nature 513: 229-232.

Laurance, W. F., B. M. Croes, N. Guissouegou, R. Buit, M. Dethier, and A. Alonso. 2008. Impacts of roads, hunting, and habitat alteration on nocturnal mammals in African rainforests. Conserv. Biol. 22: 721-732.

Laurance, W. F., B. M. Croes, L. Tchignoumba, S. A. Lahm, A. Alonso, M. E. Lee, P. CAMPBELL, and C. ONDZEANO. 2006. Impacts of roads and hunting on Central African rainforest mammals. Conserv. Biol. 20: 1251-1261.

LAURANCE, W. F., M. GOOSEM, and S. G. W. LAURANCE. 2009. Impacts of roads and linear clearings on tropical forests. Trends Ecol. Evol. 24: 659-69.

Laurance, W. F., A. Peletier-Jellema, B. Geenen, H. Koster, P. Verweij, P. Van Dijck, T. E. LOVEJOY, J. SCHLEICHER, and M. V KUJIK. 2015. Reducing the global environmental impacts of rapid infrastructure expansion. Curr. Biol. 25: 1-5.

LAURANCE, W. F., and D. C. USECHE. 2009. Environmental synergisms and extinctions of tropical species. Conserv. Biol. 23: 1427-37.

LeEs, A. C., and C. A. Peres. 2009. Gap-crossing movements predict species occupancy in Amazonian forest fragments. Oikos 118: 280-290.

LEWIS, S. L., D. P. EDWARDS, and D. GALBRAITH. 2015. Increasing human dominance of tropical forests. Science (80-. ). 349: 19-73.

MALCOLM, J. R., and J. C. RAY. 2000. Influence of timber extraction routes on central african smallmammal communities, forest structure, and tree diversity. Conserv. Biol. 14: 1623-1638.

MASON, D. 1996. Responses of Venezuelan understory birds to selective logging, enrichment Strips, and vine cutting. Biotropica 28: 296-309.

MASON, D. J., and F. E. PUTZ. 2001. Reducing the impacts of tropical forestry on wildlife. In R. Fimbel, A. Grajal, JG. Robinson (Ed.) The cutting edge: conserving wildlife in logged tropical forest. Biology and resource management in the tropics series. pp. 473-510, Columbia University Press.

Matthews, A., and A. MATTHEws. 2004. Survey of gorillas (Gorilla gorilla gorilla) and chimpanzees (Pan troglodytes troglodytes) in Southwestern Cameroon. Primates 45: 15-24. 
MEDJIBE, V. P., and F. E. PUTZ. 2012. Cost comparisons of reduced-impact and conventional logging in the tropics. J. For. Econ. 18: 242-256.

881

882

883

884

885

886

887

888

889

890

891

892

893

894

895

896

897

898

899

900

901

902

903

904

905

906

907

908

909

910

911

912

913

914

915

916

917

918

919

920

921

922

923

MedJiBe, V. P., F. E. PUTZ, and C. RoMERo. 2013. Certified and uncertified logging concessions compared in Gabon: changes in stand structure, tree species, and biomass. Environ. Manage. 51: $524-40$.

MERTENS, B., and E. F. LAMBIN. 2000. Land-cover change trajectories in southern Cameroon. Ann. Assoc. Am. Geogr. 90: 467-494.

Mertens, B., R. Poccard-Chapuis, M. G. Piketty, A. E. Lacques, and A. Venturieri. 2002. Crossing spatial analyses and livestock economics to understand deforestation processes in the Brazilian Amazon: The case of São Félix do Xingú in South Pará. Agric. Econ. 27: 269-294.

NABE-NiElSEN, J., W. SeVEriche, T. FrederiCKSEN, and L. NABE-NiELSEN. 2007. Timber tree regeneration along abandoned logging roads in a tropical Bolivian forest. New For. 34: 31-40.

Nasi, R., D. Brown, D. Wilkie, E. Bennett, C. Tutin, G. VAn Tol, and T. Christophersen. 2008. Conservation and use of wildlife-based resources: the bushmeat crisis. Technical Series 33. Secretariat of the Convention on Biological Diversity, Montreal.

Negishi, J. N., R. C. Sidle, S. NogUChI, A. R. NiK, and R. Stanforth. 2006. Ecological roles of roadside fern (Dicranopteris curranii) on logging road recovery in Peninsular Malaysia: Preliminary results. For. Ecol. Manage. 224: 176-186.

Negishi, J. N., R. C. SidLe, A. D. Ziegler, S. Noguchi, and A. R. NiK. 2008. Contribution of intercepted subsurface flow to road runoff and sediment transport in a logging-disturbed tropical catchment. Earth Surf. Process. Landforms 1191: 1174-1191.

Nepstad, D. C., A. G. Moreira, and A. A. Alencar. 1999. Flames in the rain forest: Origins, impacts and alternatives to Amazonian fires. The Pilot Program to Conserve the Brazilian Rain Forest, Brasilia.

Nepstad, D., G. Carvalho, A. C. Barros, A. Alencar, J. P. Capobianco, J. Bishop, P. Moutinho, P. LEFEBVRE, U. L. Silva, and E. Prins. 2001. Road paving, fire regime feedbacks, and the future of Amazon forests. For. Ecol. Manage. 154: 395-407.

Nepstad, D., D. McGrath, A. Alencar, A. C. Barros, G. Carvalho, M. Santilli, and M. D. C. VERA DIAZ. 2002. Frontier governance in Amazonia. Science (80-. ). 295: 629-631.

NUMMELIN, M. 1990. Relative habitat use of duikers, bush pigs, and elephants in virgin and selectively logged areas of the Kibale Forest, Uganda. Trop. Zool. 3: 111-120.

OBIDZINSKI, K., A. ANDRIANTO, and C. WIJAYA. 2007. Cross-border timber trade in Indonesia: critical or overstated problem? Forest governance lessons from Kalimantan. Int. For. Rev. 9: $526-535$.

Oliveira, P. J. C., G. P. Asner, D. E. Knapp, A. Almeyda, R. Galvan-Gildemeister, S. KeEne, R. F. RAYBIN, and R. C. SMITH. 2007. Land-use allocation protects the Peruvian Amazon. Science (80-. ). 317: 1233-1236.

Padmanaba, M., and D. SHeIL. 2014. Spread of the invasive alien species Piper aduncum via logging roads in Borneo. Trop. Conserv. Sci. 7: 35-44.

PereirA, R., J. ZWEede, G. P. ASNER, and M. KelLER. 2002. Forest canopy damage and recovery in reduced-impact and conventional selective logging in eastern Para, Brazil. For. Ecol. Manage. 168: 77-89.

Perz, S. G., C. Overdevest, M. M. CALDAS, R. T. WALKer, and E. Y. Arima. 2007. Unofficial road building in the Brazilian Amazon: dilemmas and models for road governance. Environ. Conserv. 34: 112 . 
Pfaff, A., J. Robalino, R. Walker, S. Aldrich, M. Caldas, I. De Pesquisa, E. Aplicada, A. PRESIDENTE, A. CARLOS, and C. BOHRER. 2007. Road investments, spatial spillovers, and deforestation in the Brazilian Amazon. J. Reg. Sci. 47: 109-123.

PICARD, N., L. GAZULL, and V. FREYCON. 2006. Finding optimal routes for harvesting tree access. Int. J. For. Eng. 17: 35-49.

PICARD, N., S. GOURLET-FLEURY, and É. FORNI. 2012. Estimating damage from selective logging and implications for tropical forest management. Can. J. For. Res. 42: 605-613.

PINARD, M. A., M. G. BARKER, and J. TAY. 2000. Soil disturbance and post-logging forest recovery on bulldozer paths in Sabah, Malaysia. For. Ecol. Manage. 130: 213-225.

PinARD, M. A., F. E. PUTZ, J. TAY, and T. E. SUlLiVAN. 1995. Creating timber harvest guidelines for a reduced-impact logging project in Malaysia. J. For. 93: 41-45.

Potapov, P., A. Yaroshenko, S. Turubanova, M. Dubinin, L. Laestadius, C. Thies, D. AKSENOV, A. EgOROV, Y. Yesipova, I. GlushKov, M. KARPACHEVSKIY, A. KostiKova, A. MANISHA, and E. TSYBIKOVA. 2008. Mapping the world's intact forest landscapes by remote sensing. Ecol. Soc. 13: 51.

POUlSEN, J. R., C. J. ClARK, and B. M. BOLKER. 2011. Decoupling the effects of logging and hunting on an afrotropical animal community. Ecol. Appl. 21: 1819-36.

Poulsen, J. R., C. J. Clark, G. MAVAh, and P. W. ElKan. 2009. Bushmeat supply and consumption in a tropical logging concession in northern Congo. Conserv. Biol. 23: 1597-608.

PUTZ, F. E., D. P. DYKSTRA, and R. HEINRICH. 2000. Why poor logging practices persist in the tropics. Conserv. Biol. 14: 951-956.

PUTZ, F. E., and C. ROMERO. 2015. Futures of tropical production forests. CIFOR occasional paper 143. CIFOR, Bogor, Indonesia.

PUTZ, F. E., and RUSLANDI. 2015. Intensification of tropical silviculture. J. Trop. For. Sci. 27: 285288.

Putz, F. E., P. A. Zuidema, T. Synnott, M. Peña-Claros, M. A. Pinard, D. Sheil, J. K. VAnClay, P. Sist, S. Gourlet-Fleury, B. Griscom, J. PAlMER, and R. ZaGt. 2012. Sustaining conservation values in selectively logged tropical forests: the attained and the attainable. Conserv. Lett. 5: 296-303.

PutZ, F., P. Sist, T. FrederickSEN, and D. DYKSTRA. 2008. Reduced-impact logging: Challenges and opportunities. For. Ecol. Manage. 256: 1427-1433.

RAY, J. C., and M. E. SUNQUIST. 2001. Trophic relations in a community of African rainforest carnivores. Oecologia 127: 395-408.

LE RAY, J. 1956. Les routes forestières de la Société Nationale du Cameroun. Bois Forêts des Trop. 50: $35-48$.

REDFORD, K. 1992. The empty forest. Bioscience 42: 412-422.

REID, J. W., and I. A. BowLES. 1997. Reducing the impacts of roads on tropical forests. Environ. Sci. Policy Sustain. Dev. 39: 10-35.

Robinson, J. G., K. H. ReDfoRD, and E. L. BenNetT. 1999. Wildlife harvest in logged tropical forests. Science (80-. ). 284: 595-596.

SCHMIDT, L., D. PRASETYONOHADI, and T. SWINFIELD. 2015. Restoration of artificial ponds in logging concessions: a case-study from Harapan Rainforest, Sumatra. Trop. Conserv. Sci. 8: 3344. 
SCHNEIDER, R., E. ARIMA, A. VerísSimo, C. S. JÚNIOR, and P. BARRETO. 2000. Sustainable Amazon. Limitation and opportunities for rural development. World Bank and Imazon, Brasilia.

1000

1001

1002

1003

1004

1005

1006

1007

1008

1009

1010

1011

SESSIONS, J. 2007. Forest road operations in the tropics. Springer, Berlin, Heidelberg, New York.

Sidle, R. C., S. SASAKi, M. Otsuki, S. Noguchi, and N. AbDUl Rahim. 2004. Sediment pathways in a tropical forest: Effects of logging roads and skid trails. Hydrol. Process. 18: 703-720.

Sidle, R. C., A. D. Ziegler, J. N. Negishi, A. R. NiK, R. SieW, and F. TuRKelboOM. 2006. Erosion processes in steep terrain-Truths, myths, and uncertainties related to forest management in Southeast Asia. For. Ecol. Manage. 224: 199-225.

Siegert, F., G. Ruecker, A HinRICHS, and A A HoffmanN. 2001. Increased damage from fires in logged forests during droughts caused by El Niño. Nature 414: 437-440.

SIST, P. 2000. Reduced-impact logging in the tropics: objectives, principles and impacts. Int. For. Rev. 2: 3-10.

Sist, P., D. SheiL, K. KARTAWINATA, and H. PRIYADI. 2003. Reduced-impact logging in Indonesian Borneo: some results confirming the need for new silvicultural prescriptions. For. Ecol. Manage. 179: 415-427.

Steege, H., R. G. A. Boot, L. C. Brouwer, J. C. Caesar, R. C. Ek, D. S. Hammond, P. P. Haripersaud, P. Van Der Hout, V. G. Jetten, A. J. Van KeKem, M. A. Kellman, Z. Khan, A. M. Polak, T. L. Pons, J. Pulles, D. RaAimakers, S. A. Rose, J. J. VAn Der SANDEN, and R. J. ZAGT. 1996. Ecology and logging in a tropical rain forest in Guyana. With recommendations for forest management. The Tropenbos Foundation, Wageningen, The Netherlands.

Swaine, M. D., and V. K. AGYEMAN. 2008. Enhanced tree recruitment following logging in two forest reserves in Ghana. Biotropica 40: 370-374.

TAKADA, M., T. YAMADA, I. SHAMSUDIN, and T. OKUDA. 2015. Spatial variation in soil respiration in relation to a logging road in an upper tropical hill forest in Peninsular Malaysia. Tropics 24: 1-9.

Theuerkauf, J., H. EllenberG, W. E. WaitKuwait, and M. MÜhlenberg. 2001. Forest elephant distribution and habitat use in the Bossematié Forest Reserve, Ivory Coast. Pachyderm 30: 3743.

ThiOllay, J. M. 1997. Disturbance, selective logging and bird diversity:a Neotropical forest study. Biodivers. Conserv. 6: 1155-1173.

TIANI, A., G. AKWAH, and J. NGUIÉBOURI. 2005. Women in Campo-Ma'an National Park: uncertainties and adaptations in Cameroon. In C. Pierce Colfer (Ed.) The equitable forest : diversity, community, and resource management. pp. 131-149, Resources for the Future and Center for International Forestry Research, Washington, DC.

Uhl, C., P. Barreto, A. Veríssimo, E. Vidal, P. Amaral, A. C. Barros, C. Souza, J. Johns, and J. GERWING. 1997. Natural resource management in the Brazilian Amazon. Bioscience 47: 160168.

UHL, C., and I. C. G. VIEIRA. 1989. Ecological impacts of selective logging in the Brazilian Amazon: a case study from the Paragominas region of the state of Para. Biotropica 21: 98-106.

VANTHOMme, H., J. KolOwSKi, L. Korte, and A. AlONSO. 2013. Distribution of a community of mammals in relation to roads and other human disturbances in Gabon, central Africa. Conserv. Biol. 27: 281-91.

Veldman, J. W., B. Mostacedo, M. Peña-Claros, and F. E. Putz. 2009. Selective logging and fire as drivers of alien grass invasion in a Bolivian tropical dry forest. For. Ecol. Manage. 258: $1643-1649$. 
VeldMAN, J. W., and F. E. PUTZ. 2010. Long-distance dispersal of invasive grasses by logging vehicles in a tropical dry forest. Biotropica 42: 697-703.

1014

1015

1016

1017

1018

1019

1020

1021

1022

1023

1024

1025

1026

1027

1028

1029

1030

1031

1032

1033

1034

1035

1036

1037

1038

1039

1040

1041

1042

1043

1044

1045

1046

1047

1048

1049

1050

1051

1052

1053

1054
Verhegghen, A., H. Eva, G. Ceccherini, F. Achard, V. Gond, S. Gourlet-Fleury, and P. CERUTTI. 2016. The potential of Sentinel satellites for burnt area mapping and monitoring in the Congo Basin forests. Remote Sens. 8: 986.

Veríssimo, A., P. BARRETO, R. TARIFA, and C. UHL. 1995. Extraction of a high-value natural resource in Amazonia: the case of mahogany. For. Ecol. Manage. 72: 39-60.

VAN VLIET, N., and R. NASI. 2008. Mammal distribution in a Central African logging concession area. Biodivers. Conserv. 17: 1241-1249.

WALKER, R., and T. E. SMITH. 1993. Tropical deforestation and forest management under system of concession logging: A decision-theoretic analysis. J. Reg. Sci. 33: 387-419.

WALSh, P., P. HENSCHEL, and K. ABERNETHY. 2004. Logging speeds little red fire ant invasion of Africa. Biotropica 6: 637-641.

Walsh, R. P. D., K. Bidin, W. H. Blake, N. A Chappell, M. a Clarke, I. Douglas, R. Ghazali, A M. SAYER, J. SUHAIMI, W. TYCH, and K. V ANNAMMALA. 2011. Long-term responses of rainforest erosional systems at different spatial scales to selective logging and climatic change. Philos. Trans. R. Soc. B Biol. Sci. 366: 3340-3353.

WELLS, C. H. 2002. Forest harvesting roads: meeting operational social and environmental needs with efficiency and economy. In T. Enters, P. B. Durst, G. B. Applegate, P. C. S. Kho, and G. Man (Eds.) Applying reduced impact logging to advanced sustainable forest management. pp. 37-47, Food and Agriculture Organization of the United Nations, Bangkok.

WHITE, L. J. . T. . 1994. The effects of commercial mechanised selective logging on a transect in lowland rainforest in the Lope Reserve, Gabon. J. Trop. Ecol. 10: 313-322.

WiLKIE, D. S., J. G. SidLE, and G. C. BoundZANGA. 1992. Mechanized logging, market hunting, and a bank loan in Congo. Conserv. Biol. 6: 570-580.

Wilkie, D., E. Shaw, F. Rotberg, G. Morelli, and P. Auzel. 2000. Roads, development, and conservation in the Congo Basin. Conserv. Biol. 14: 1614-1622.

Willott, A. S. J., D. C. Lim, S. G. Compton, and S. L. SuTTON. 2000. Effects of selective logging on the butterflies of a Bornean rainforest. Conserv. Biol. 14: 1055-1065.

WONG, W. M., and M. LINKIE. 2013. Managing sun bears in a changing tropical landscape. Divers. Distrib. 19: 700-709.

WOODWARD, C. L. 1996. Soil compaction and topsoil removal effects on soil properties and seedling growth in Amazonian Ecuador. For. Ecol. Manage. 82: 197-209.

WUNDER, S. 2005. Oil wealth and the fate of the forest: a comparative study of eight tropical countries. Taylor \& Francis, Oxford.

YAMADA, T., M. NiINO, S. YoshidA, T. HosaKA, and T. OKUDA. 2014. Impacts of logging road networks on dung beetles and small mammals in a Malaysian production forest: implications for biodiversity safeguards. Land 3: 639-657.

Ziegler, A., J. Negishi, R. C. SidLe, T. Gomi, S. Noguchi, and A. R. NiK. 2007. Persistence of road runoff generation in a logged catchment in Peninsular Malaysia. Earth Surf. Process. Landforms 32: $1947-1970$. 


\section{TABLES}

TABLE 1: Widths of primary and secondary logging roads in tropical forests, separated between road track (the surface on which vehicles travel) and corridor (full width of forest cleared including on both sides of the track).

\begin{tabular}{|c|c|c|c|c|c|c|}
\hline \multicolumn{2}{|c|}{ Track width (m) } & \multicolumn{2}{|c|}{ Corridor width (m) } & \multirow{2}{*}{$\begin{array}{l}\text { Countryl } \\
\text { Continent }\end{array}$} & \multirow{2}{*}{$\begin{array}{l}\text { Forest } \\
\text { certifi- } \\
\text { cation }\end{array}$} & \multirow[t]{2}{*}{ Reference } \\
\hline Primary & Secondary & Primary & Secondary & & & \\
\hline 6.6 & & 24.7 & & Bolivia & & $\begin{array}{l}\text { Gullison \& Hardner } \\
\text { (1993) }\end{array}$ \\
\hline \multirow[t]{2}{*}{5.2} & 4.6 & 13.3 & 10.5 & Bolivia & & $\begin{array}{l}\text { Jackson et al. } \\
\text { (2002) }\end{array}$ \\
\hline & 3.6 & & $\begin{array}{l}5.5(5.3- \\
5.7)^{\mathrm{a}}\end{array}$ & Brazil & & Johns et al. (1996) \\
\hline \multirow[t]{3}{*}{4.3} & 5.1 & 10.1 & 9.8 & Brazil & & $\begin{array}{l}\text { Feldpausch et al. } \\
\text { (2005) }\end{array}$ \\
\hline & & 12.5 & 3.0 & Brazil & & Uhl \& Vieira (1989) \\
\hline & $\begin{array}{l}3.3(3.0- \\
3.5)^{\mathrm{a}}\end{array}$ & & $5.8(5-6.5)$ & Costa Rica & & $\begin{array}{l}\text { Guariguata \& Dupuy } \\
\text { (1997) }\end{array}$ \\
\hline \multirow[t]{3}{*}{7} & & 17 & & Cameroon & & Hoeven (2010) \\
\hline & & 25 & 20 & Cameroon & & $\begin{array}{l}\text { Gideon Neba et al. } \\
(2014)\end{array}$ \\
\hline & 5.3 & & 17.2 & Cameroon & & $\begin{array}{l}\text { Kleinschroth, } \\
\text { Healey, Sist, et al. } \\
\text { 2016), unpublished } \\
\text { material }\end{array}$ \\
\hline 7.9 & 6.4 & & & $\begin{array}{l}\text { Central } \\
\text { African } \\
\text { Republic }\end{array}$ & & $\begin{array}{l}\text { Malcolm \& Ray } \\
(2000)\end{array}$ \\
\hline 6.4 & 5.1 & & & $\begin{array}{l}\text { Central } \\
\text { African } \\
\text { Republic }\end{array}$ & & $\begin{array}{l}\text { Durrieu de Madron } \\
\text { et al. }(2000)\end{array}$ \\
\hline \multirow[t]{5}{*}{6.8} & & 22.6 & & Gabon & & Medjibe et al. (2013) \\
\hline & 4.1 & & 15.1 & Gabon & FSC & Medjibe et al. (2013) \\
\hline & 7.9 & & 66.6 & Gabon & None & Medjibe et al. (2013) \\
\hline & & 40 & 25 & $\begin{array}{l}\text { Republic of } \\
\text { Congo }\end{array}$ & & FAO (1995) \\
\hline & 7.7 & & 25.3 & $\begin{array}{l}\text { Republic of } \\
\text { Congo }\end{array}$ & & $\begin{array}{l}\text { Kleinschroth, } \\
\text { Healey, Sist, et al. } \\
\text { (2016), unpublished } \\
\text { material }\end{array}$ \\
\hline
\end{tabular}




\begin{tabular}{|c|c|c|c|c|c|c|}
\hline \multirow{4}{*}{$3 \cdot 49$} & & 30 & 20 & \multicolumn{2}{|c|}{ Central Africa } & \multirow{2}{*}{$\begin{array}{l}\text { Estève (1983) } \\
\text { Ziegler et al. (2007) }\end{array}$} \\
\hline & & & & Malaysia & & \\
\hline & & 32.75 & & Indonesia & FSC & $\begin{array}{l}\text { Griscom et al. } \\
(2014)\end{array}$ \\
\hline & & 31.78 & & Indonesia & None & $\begin{array}{l}\text { Griscom et al. } \\
(2014)\end{array}$ \\
\hline 5.5 & 4 & 17.4 & 6.8 & America $^{b}$ & & \\
\hline 7.2 & 6 & 28.5 & 40.9 & Africa $^{b}$ & & \\
\hline 3.5 & & 32.3 & & $A_{s i a}{ }^{b}$ & & \\
\hline 6.4 & 5.1 & 24.9 & 15.1 & Global $^{\mathrm{c}}$ & & \\
\hline 5.8 & 5.26 & 24.1 & 19.3 & Global $^{d}$ & & \\
\hline
\end{tabular}

${ }^{a}$ Mean and range (in brackets) of values given in the paper

${ }^{\mathrm{b}}$ Mean summarized for values of the respective continent

${ }^{\mathrm{c}}$ Median summarized for all values

${ }^{\mathrm{d}}$ Mean summarized for all values 
TABLE 2: Proportion of the overall surface area of the forest (reference area defined for each study) cleared for road building.

\begin{tabular}{|c|c|c|c|}
\hline $\begin{array}{l}\text { Proportion of forest } \\
\text { area cleared for } \\
\text { road building }\end{array}$ & $\begin{array}{l}\text { Country/ } \\
\text { Continent }\end{array}$ & Reference area & Reference \\
\hline $1 \%$ & Brazil & "Overall logged area" & Feldpausch et al. (2005) \\
\hline $8 \%$ & Brazil & "Total logged forest area" & Uhl \& Vieira (1989) \\
\hline $1.05 \%$ & Bolivia & "Section of logged area" & Gullison \& Hardner (1993) \\
\hline $2.1 \%$ & Bolivia & "Harvesting block" & Jackson et al. (2002) \\
\hline $1.3(0.6-2) \%$ & Brazil & $\begin{array}{l}\text { "Total area of four harvest } \\
\text { blocks" }\end{array}$ & $\begin{array}{l}\text { Asner et al. (2002) Pereira } \\
\text { et al. (2002) }\end{array}$ \\
\hline $0.7 \%$ & Belize & "One-year logging coupe" & Arevalo et al. (2016) \\
\hline $2 \%$ & Cameroon & $\begin{array}{l}\text { "Annual allowable cut } \\
\text { area" }\end{array}$ & Gideon Neba et al. (2014) \\
\hline $0.74 \%$ & Cameroon & $\begin{array}{l}\text { "Average across seven } \\
\text { logging concessions" }\end{array}$ & $\begin{array}{l}\text { Kleinschroth, Healey, Sist, } \\
\text { et al. (2016) }\end{array}$ \\
\hline $0.8 \%$ & $\begin{array}{l}\text { Central African } \\
\text { Republic }\end{array}$ & $\begin{array}{l}\text { "Annual allowable cut } \\
\text { area" }\end{array}$ & $\begin{array}{l}\text { Durrieu de Madron et al. } \\
(2000)\end{array}$ \\
\hline $6.4 \%$ & Gabon & $\begin{array}{l}\text { "Logged section of overall } \\
\text { forest area" }\end{array}$ & White (1994) \\
\hline $1.7 \%$ & Republic of Congo & NA & FAO (1995) \\
\hline $0.8 \%$ & Republic of Congo & $\begin{array}{l}\text { "Average across four } \\
\text { logging concessions" }\end{array}$ & $\begin{array}{l}\text { Kleinschroth, Healey, Sist, } \\
\text { et al. (2016) }\end{array}$ \\
\hline $1.84(1.3-2.4) \%$ & Central Africa $^{a}$ & NA & Estève (1983) \\
\hline $4(3.3-4.7) \%$ & Indonesia ${ }^{a}$ & "Logging unit" & Pinard et al. (2000) \\
\hline $4.8 \%$ & Malaysia & "Logging compartment" & Johns (1988) \\
\hline $0.6-8 \%$ & America $^{b}$ & & \\
\hline $0.74-6.4 \%$ & Africa $^{\mathrm{b}}$ & & \\
\hline $3.3-4.8 \%$ & Asia $^{\mathrm{b}}$ & & \\
\hline $1.7 \%$ & Global $^{c}$ & & \\
\hline $2.48 \%$ & Global $^{d}$ & & \\
\hline \multicolumn{4}{|c|}{${ }^{\mathrm{a}}$ Mean and range (in brackets) of values given in the paper } \\
\hline \multicolumn{4}{|c|}{${ }^{b}$ Range (minimum and maximum values) summarized for respective continent } \\
\hline${ }^{\mathrm{c}}$ Median summariz & for all values & & \\
\hline
\end{tabular}




\section{FIGURE LEGENDS}

FIGURE 1: Example of a secondary logging road in Republic of Congo annotated with crosssection measures and their respective names used in the text.

FIGURE 2: Conceptual model of the temporal evolution of logging roads, principal actors, potential impacts linked to each phase and measures to mitigate them.

FIGURE 3: Comparison of the impact intensity of two hypothetical logging road development trajectories, depending on follow-up use (see Figure 2) or successful closure after logging until the next logging cycle. A darker shading of the orange bar indicates higher impact intensity, based on an estimated accumulation of impacts described in the main text. 


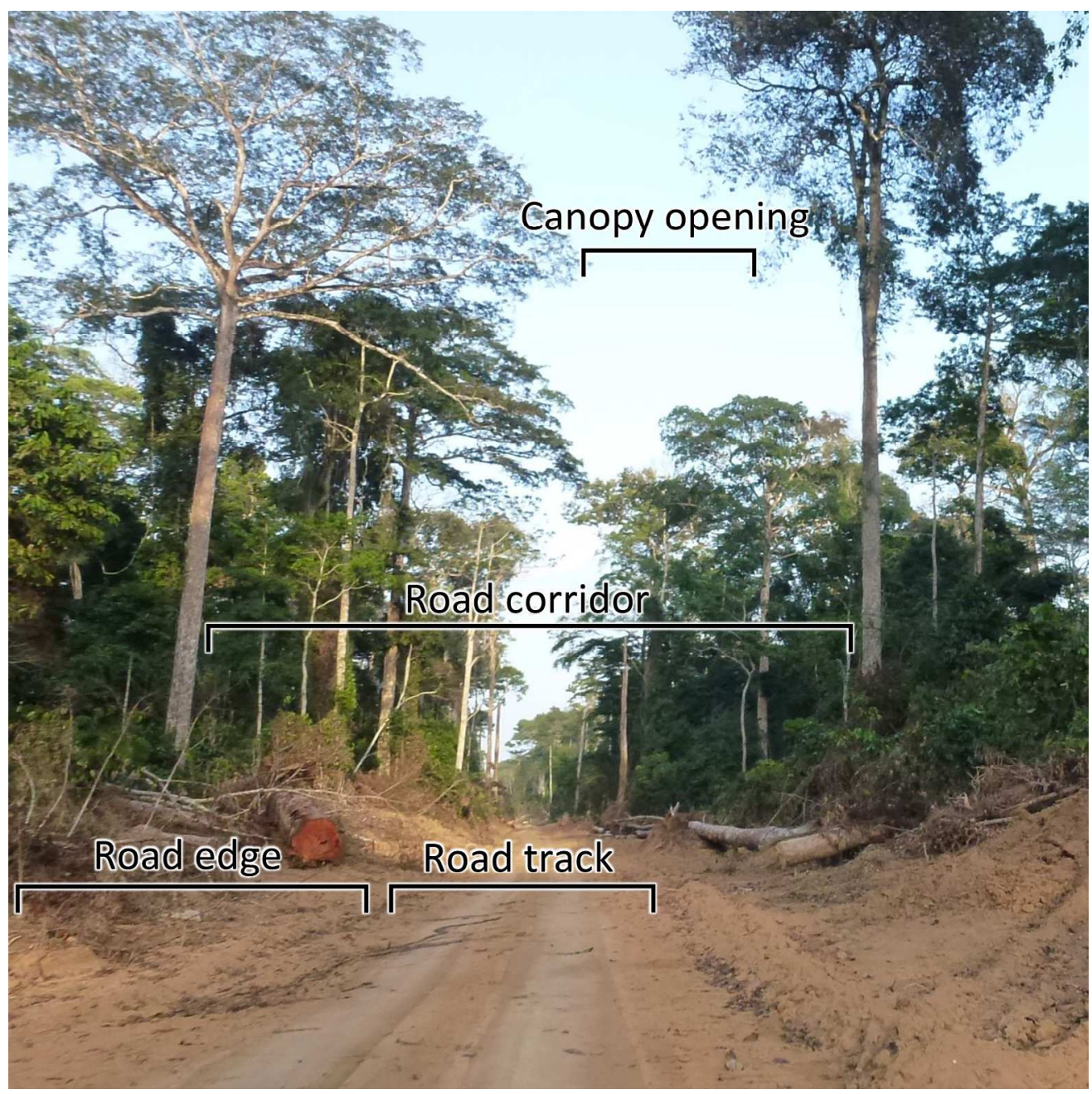

Example of a secondary logging road in Republic of Congo annotated with cross-section measures and their respective names used in the text. Figure 1 $207 \times 206 \mathrm{~mm}(300 \times 300$ DPI $)$ 
Conceptual model of the temporal evolution of logging roads, principal actors, potential impacts linked to each phase and measures to mitigate them.

Figure 2

$222 \times 285 \mathrm{~mm}(300 \times 300 \mathrm{DPI})$ 
Comparison of the impact intensity of two hypothetical logging road development trajectories, depending on follow-up use (see Figure 2) or successful closure after logging until the next logging cycle. A darker shading of the orange bar indicates higher impact intensity, based on an estimated accumulation of impacts described in the main text.

Figure 3

$211 \times 112 \mathrm{~mm}(300 \times 300 \mathrm{DPI})$ 